\title{
Novel Reporting of Community Acquired Methicillin Resistant Staphylococcus aureus (CA-MRSA) Strain at a Tertiary Care Centre
}

\author{
Prashant Jindamwar*, P Roy, C.N. Chaudhary, N. Grover, \\ Patil Shivraj and Khajuriya Atul
}

\author{
Hospital Laboratory, Base Hospital, SN Bannerjee Road, Barrackpore-700120, \\ Dist-24 North Parganas, West Bengal, India \\ *Corresponding author
}

\begin{tabular}{|c|c|}
\hline & A B S T R A C T \\
\hline & $\begin{array}{l}\text { Recently MRSA has become significant problem in hospitals and community. } \\
\text { There has been few works on complete phenotyping, SCCmec typing and }\end{array}$ \\
\hline $\begin{array}{l}\text { Ke y w or d s } \\
\text { CA-MRSA, } \\
\text { PVL gene, } \\
\text { SCCmec typing, } \\
\text { SCCmecIV } \\
\text { subtyping. }\end{array}$ & $\begin{array}{l}\text { SCCmecIV subtyping. With this background, this study was conducted to detect } \\
\text { the prevalence, susceptibility pattern, association of PVL gene with CA- } \\
\text { MRSA strains with SCCmec typing and SCCmecIV subtyping. Study was carried } \\
\text { out at a tertiary carecentre for duration of } 2 \text { years. Samples were collected from } \\
\text { patients as CDC-2000. Total } 395 \text { samples were collected, MRSA was isolated } \\
\text { from } 80 \text { samples }(80 / 395 ; 20.2 \%) \text {. These strains were resistant to commonly used } \\
\text { antibiotics but no VRSA isolated. mecA and PVL gene were present in } 72(90 \%)\end{array}$ \\
\hline Article Info & $\begin{array}{l}\text { and } 48 \text { isolates }(60 \%) \text {. The prevalent strain in the community was SCCmecIVc } \\
(40 \%) \text {. The sequences were deposited to genebank with accession }\end{array}$ \\
\hline $\begin{array}{l}\text { Accepted: } \\
\text { 20 September } 2016 \\
\text { Available Online: } \\
10 \text { October } 2016\end{array}$ & $\begin{array}{l}\text { NO.KF710034and BANK LT } 1664623 \text {. The other SCCmec types were not present } \\
\text { in the MRSA isolates. Worldwide we were the } 7 \text { th person and from India we were } \\
\text { the } 2 \text { nd to deposit the strain of similar sequences. There is change in susceptibility } \\
\text { pattern. Most of the genetic elements were carried by isolates. In future proper } \\
\text { measures to be adopted to reduce the prevalence. }\end{array}$ \\
\hline
\end{tabular}

\section{Introduction}

Staphylococcus aureus has been recognized as an important cause of human disease for more than 100 years (Lowy, 1998) as it carries a wealth of pathogenic determinants, which promote tissue colonization, damage and distant diseases. S. aureus has a niche preference for the anterior nares, in adults (Kluytmans et al., 1997; Wertheim et al., 2005) and is shed on healthy skin, including axilla and perineum. Nasal carriage rate varies from $10 \%$ to $40 \%$ in both the community and the hospital environment (Que, 2010). Nasal carriage has become a mode of persistence and spread of multiresistant staphylococci, Methicillin Resistant Staphylococcus aureus (MRSA). MRSA are resistant to practically all available antibiotics, leading threat to public health in the hospital (for 03 decades) and in the community since the beginning of this century (Que, 2010). 
Staphylococcal chromosome cassette (SCC) $m e c$ is a genetic island in MRSA controlling drug resistance, in that mec (Ito et al., 2003) element resistance to methicillin and mediates $\beta$-lactam resistance. SCCmec is DNA piece $(15-60 \mathrm{~kb})$ bounded by direct and inverted repeats to facillitate integration at a homologous site. Recombinases $c c r A$ and $c c r B$ in SCCmec are critical genes which can mediate mobilization of the DNA.

SCCmec are discriminated on the basis of the structure of their $c c r A-B$ and mecA complexes (Ito et al., 2001). SCCmec I, II, and III are shown to belong to health care associated clones (HA-MRSA). HA-MRSA harbours multiple resistance determinants of relatively large sizes (35 to $60 \mathrm{~kb}$ ) with difficulty to mobilize. While SCCmec types IV, V, and VI are associated with community associated strains (CA-MRSA). SCCmec type $\mathrm{V}$ was reported for the first time in Australia (Ito et al., 2004). Community acquired $\mathrm{SCCmec}$ types harbour much smaller loci (about $15 \mathrm{~kb}$ ) and do not carry multidrug resistant genes. While they appear to be associated with other elements in the same bacterium, including PantonValentine toxin and multiple staphylococcal exotoxins (set) genes.

CA-MRSA seems to be less clonal with small SCCmec cassettes, so these are easily mobilized. It is now clear that CA-MRSA has not arisen from HA-MRSA that permeated the community but has emerged independently by acquiring its SCCmec most likely from CoNS donors. Whether its spread is from the widespread use of $\beta$ lactams or because its SCCmec and global genetic context provide other advantages to the bacterium is as yet undetermined.

Although originally confined to the hospital environment MRSA has emerged as a community-acquired infection over the last decade. CA-MRSA is not associated with any risk factors. Predominantly CA-MRSA causes primarily skin and soft tissue infections and sometimes rapidly fatal necrotizing pneumonia, necrotizing fasciitis bone $\&$ joint infections.

CDC defined CA-MRSA infection based on

- An outpatient or within $48 \mathrm{hr}$ of hospitalization

- Should lacks risk factors as hemodialysis, surgery, residence in a long-term care facility or hospitalization during the previous year, the presence of an indwelling catheter or a percutaneous device at the time of culture, or previous isolation of MRSA from the patient (David et al., 2008; Morrison et al., 2006).

- Definition was used to demonstrate MRSA infections among healthy people.

- Definition was further modified for Active Bacterial Core Surveillance Program for invasive MRSA infections and to exclude the previous isolation of MRSA as a criterion for HA-MRSA.

Numerous outbreaks of community-based infection affecting diverse groups of professionals, different regions have occurred in the last 10 years. These outbreaks implied dramatic change in the epidemiology of MRSA infections. Risk factors which were common to outbreaks were poor hygienic conditions, close contact, contaminated material, and damaged skin. Limited numbers of MRSA strains were responsible for the outbreaks (USA-300 in US).

MRSA prevalence varied in India depending upon the number of factors. one study which 
involved 5-15 yrs age group had prevalence 19\% (Ramana et al., 2009). Apart from the diversity in prevalence there was clonal expansion of multi drug resistant strains as detected by Namita D'suza, et al., in Mumbai, India (D'Souza et al., 2010).

Keeping this background, this study was designed with an aim to determine the prevalence and further to carry out molecular characterization of CA-MRSA strains by easy, simple and time cumbersome methods.

\section{Materials and Methods}

A cross-sectional study was conducted from July 2011 to July 2013 at department of Microbiology and affiliated tertiary care hospital. Inclusion criterion for the study was followed as per definition of CA-MRSA by CDC-2000. Various clinical samples like swabs from pus, fluids, discharge, anterior nasal site and hand flora were received from various OPDs.

Standard phenotypic methods (Gram stain, colony morphology, catalase test, slide and tube coagulase test, bacitracin resistance, Furazolidine sensitivity, Deoxyribonuclease (DNase) Test, Phosphatase Test, Mannitol Fermentation Test) were used for identification. Afterwards MRSA isolates were identified by using the Cefoxitin (CX$30 \mu \mathrm{g}$ ) disk as per CLSI guidelines (Clinical and laboratory standards institute, 2009). All these isolates were tested for their susceptibility to antibiotics active against Gram positive cocci by Kirby Bauer disc diffusion method. However vancomycin resistance was detected by Vancomycin Screen Agar. Molecular characterization was carried out by detection of $m e c A$ genes, $P V L$ toxin, SCCmec typing into types I to type $\mathrm{V}$ and SCCmecIV subtyping into SCCmecIVa, b, c and d. DNA extraction was done by using the QIAamp DNA mini kits from QIAGEN, Germany as per Manufacturer's instructions. DNA extraction was done on the same day after phenotypic identification of MRSA. DNA was stored at $-70^{\circ} \mathrm{C}$ until the PCR. Two sets of multiplex PCRs were carried out separately. In the first PCR (PCR-1) mecA and PVL gene were detected. In the second PCR (PCR-2) SCCmec typing and SCCmecIV subtyping was carried out. Standard published primers and thermocycling conditions were followed as per McClure, et al., for PCR-1and Moussa, et al., for PCR-2. In PCR-1, positive control used for mecA gene and LeukS/F-PV gene were respectively ATCC MRSA-43300 and ATCC25923. In PCR-2, an internal positive control was used, whose sequences were identified as similar to $\mathrm{SCCmecIVc.} \mathrm{Later} \mathrm{on} \mathrm{the} \mathrm{sequences} \mathrm{were}$ deposited to gene bank with accession no KF710034 and BANK LT 1664623. This KF710034 and BANK LT 1664623 were positive control for subsequent PCRs. In both PCRs, ATCC29213 served as negative control.

\section{Results and Discussion}

Out of 395 samples Staphylococcus aureus and MRSA were isolated from 90 and 80 samples respectively. The prevalence of Staphylococcus aureus in the present study was $22.7 \%$ and that of MRSA infection was $20.2 \%$. There was change in susceptibility pattern of these MRSA isolates towards regularly used antibiotics. However there was no isolate which was resistant to linezolid and vancomycin.

Sample wise isolation of MRSA is briefed in Table-1. Majority of isolation was from both nasal and hand flora of patients attending OPDs (51.3\%). Subsequent sample was pus swabs $(26.2 \%)$ while the remaining $22.5 \%$ involved wound swabs, aural swabs, throat swabs and urine.

Gender was distribution was shown in table- 
2. $57.5 \%$ of MRSA were from 46 male patients and $42.5 \%$ were from 34 female patients. Thus more of male patients were carrying MRSA. The male to female ratio of MRSA carriage was 1.3:1 (M: F). Age distribution in the present study had ranged from 09 months to 77 years of age. Table-3 showed the distribution of MRSA as per age and gender wise. Maximum (35\%) isolates were from age group 20-29 years, subsequent age group was above 60 yrs $(18.7 \%)$. Thus the reproductive age group is affected maximally in female patients than the aged \& debilitated one.

OPD wise distribution of MRSA isolates is given in Table-4. Highest MRSA isolates $(28.5 \%)$ were from surgical OPD. Details of antimicrobial susceptibility pattern are showed in Table-5. There was change in the susceptibility pattern of all MRSA isolates to the commonly used antibiotics. All these isolates $(100 \%)$ were resistant to penicillin while $48.8 \%$ were resistant to cotrimoxazole. There was no isolate which was resistant to Linezolid and vancomycin. No VRSA was detected out of the MRSA isolates.

\section{Molecular characterization of MRSA}

90\% of mecA gene, $60 \%$ of $P V L$ gene was detected in PCR-1. In PCR-2 the prevalent strain in the regional community was SCCmecIV with subtype SCCmecIVc detected in $40 \%$ of MRSA isolates. The sequences were deposited to genebank with accession NO.KF710034and BANK LT 1664623. The other SCCmec types were not present in the MRSA isolates. The details are shown in fig- 1 \& fig- 2 for PCR-1 \& PCR-2 respectively.

There is variation in prevalence of MRSA as confirmed by various studies. The fact of concern is the rise in prevalence of MRSA as shown by NNIS survey with the increase in hospital prevalence rate from $2.4 \%$ in 1975 to $29 \%$ in 1991 (Panlilio et al., 1992). In the present study, MRSA prevalence was $20.2 \%$ which corroborated other studies. Ashok pathak et al., carried out the study on nasal carriage of MRSA in healthy preschool children in Ujjain, India. They had shown the prevalence rate of MRSA was $16.3 \%$. High percentage of MRSA isolation from the present study might be because of the more number of nasal swab samples compared to other samples.

The median age for adults infected with CAMRSA varied from 20 to 47 years. The maximum numbers of patients were from age group of 20 yrs to 59 yrs. Though MRSA does not show predilection for any particular gender, total percentages of MRSA isolation in the present study, from male and female were respectively $57.5 \%$ and $42.5 \%$. There was higher incidence of MRSA in male population compared to female population. These similar findings, higher incidence of MRSA infection among males has also been reported by Chua et al., which correlated with our findings.

CA-MRSA is an emerging problem in the obstetric population with most common presentation as skin or soft tissue infection involving multiple sites. Recurrent skin abscesses during pregnancy should raise prompt investigation for MRSA (Laibl et al., 2005). In the present study also there was $53 \%$ involvement of women patients attending obstetric OPD. These findings raised suspicion of CA-MRSA as an emerging infection in obstetric populations in our setting.

All the MRSA isolates were $100 \%$ resistant to penicillin and $100 \%$ sensitive to Linezolid; similar results were reported by Kaleem et al., In the present study no VRSA was isolated, while all these MRSA isolates had shown increase in resistance 
(30-48.8\%) with the other antibiotics. Similar type of sensitivity was demonstrated by INSAR group of India and Kaleem et al., In the past CA-MRSA strains were not multidrug resistant, but in the present study most of the isolates were multi drug resistant, a matter of concern.

Table.1 Sample wise distribution of MRSA $(n=80)$

\begin{tabular}{|l|c|c|}
\hline Nature of specimen & Number of specimens & $\begin{array}{c}\text { Percentage (\%) of isolation } \\
\text { from sample }\end{array}$ \\
\hline Nasal swab & 28 & 35 \\
\hline Pus swab & 21 & 26.2 \\
\hline Hand swab & 13 & 16.3 \\
\hline wound swab & 06 & 7.5 \\
\hline Aural swab & 05 & 6.2 \\
\hline Throat swab & 05 & 6.2 \\
\hline Urine & 02 & 2.6 \\
\hline Total & 80 & 100 \\
\hline
\end{tabular}

Table.2 Gender wise distribution of MRSA $(n=80)$

\begin{tabular}{|l|c|c|c|}
\hline Sample & Male & Female & $\begin{array}{c}\text { Total Percentage (\%) of isolation } \\
\text { from both male and female }\end{array}$ \\
\hline Nasal swab & 10 & 18 & 35 \\
\hline Pus swab & 15 & 06 & 26.2 \\
\hline Hand swab & 08 & 05 & 16.3 \\
\hline wound swab & 05 & 01 & 7.5 \\
\hline Aural swab & 04 & 01 & 6.3 \\
\hline Throat swab & 03 & 02 & 6.3 \\
\hline Urine & 01 & 01 & 2.4 \\
\hline Total & 46 & 34 & 100 \\
\hline
\end{tabular}

Table.3 Age and Gender wise distribution of MRSA $(n=80)$

\begin{tabular}{|c|c|c|c|c|}
\hline Age in Years & $\begin{array}{c}\text { Male } \\
\text { (Percentage) }\end{array}$ & $\begin{array}{c}\text { Female } \\
\text { (Percentage) }\end{array}$ & Total & $\begin{array}{c}\text { Total Percentage (\%) } \\
\text { of isolation }\end{array}$ \\
\hline$<9$ & $07(8.7)$ & $02(2.5)$ & 09 & 11.2 \\
\hline $10-19$ & $04(5)$ & $04(5)$ & 08 & 10 \\
\hline $20-29$ & $10(12.5)$ & $18(22.5)$ & 28 & 35 \\
\hline $30-39$ & $07(8.7)$ & $03(3.8)$ & 10 & 12.5 \\
\hline $40-49$ & $03(3.8)$ & $02(2.5)$ & 05 & 6.3 \\
\hline $50-59$ & $03(3.8)$ & $02(2.5)$ & 05 & 6.3 \\
\hline$>60$ & 12 & 03 & 15 & 18.7 \\
\hline Total & 46 & 34 & 80 & 100 \\
\hline
\end{tabular}


Table.4 OPD and Gender wise isolation of MRSA $(n=80)$

\begin{tabular}{|l|c|c|c|c|}
\hline \multicolumn{1}{|c|}{ OPD } & $\begin{array}{c}\text { Male } \\
\text { (percentage) }\end{array}$ & $\begin{array}{c}\text { Female } \\
\text { (percentage) }\end{array}$ & $\begin{array}{c}\text { Total } \\
\text { (Male+Female) }\end{array}$ & $\begin{array}{c}\text { Total Percentage (\%) of } \\
\text { isolation from OPDs }\end{array}$ \\
\hline Medicine & $14(17.5)$ & $04(5)$ & 18 & 22.5 \\
\hline Surgery & $17(21.3)$ & $06(7.5)$ & 23 & 28.8 \\
\hline Obstetrics & $00(0)$ & $18(22.5)$ & 18 & 22.5 \\
\hline Paediatrics & $07(8.8)$ & $04(5)$ & 11 & 5.8 \\
\hline Eye & $03(3.8)$ & $01(1.2)$ & 4 & 7.4 \\
\hline ENT & $05(6.2)$ & $01(1.2)$ & 6 & 100 \\
\hline Total & $46(57.5)$ & $34(42.5)$ & 80 & 5 \\
\hline
\end{tabular}

Table.5 Antimicrobial susceptibility pattern of MRSA isolates $(n=80)$

\begin{tabular}{|l|c|c|c|}
\hline \multicolumn{1}{|c|}{ Drug $(\mu \mathrm{g})$} & $\begin{array}{c}\text { Sensitive } \\
(\text { Percentage })\end{array}$ & $\begin{array}{c}\text { Intermediate } \\
(\text { Percentage })\end{array}$ & $\begin{array}{c}\text { Resistant } \\
\text { (Percentage) }\end{array}$ \\
\hline Penicillin $(10 \mathrm{units})$ & $0(0)$ & $0(0)$ & $80(100)$ \\
\hline Erythromycin $(15 \mu \mathrm{g})$ & $28(35)$ & $19(23.7)$ & $33(41.3)$ \\
\hline Clindamycin $(2 \mu \mathrm{g})$ & $39(48.8)$ & $17(21.2)$ & $24(30)$ \\
\hline Ciprofloxacin $(5 \mu \mathrm{g})$ & $28(35)$ & $15(18.7)$ & $37(46.3)$ \\
\hline $\begin{array}{l}\text { Cotrimoxazole } \\
(1.25 / 23.75 \mu \mathrm{g})\end{array}$ & $18(22.5)$ & $23(28.7)$ & $39(48.8)$ \\
\hline Gentamicin $(10 \mu \mathrm{g})$ & $32(40)$ & $20(25)$ & $28(35)$ \\
\hline Linezolid $(30 \mu \mathrm{g})$ & $80(100)$ & $0(0)$ & $0(0)$ \\
\hline
\end{tabular}

Molecular characterization of MRSA by PCR-1

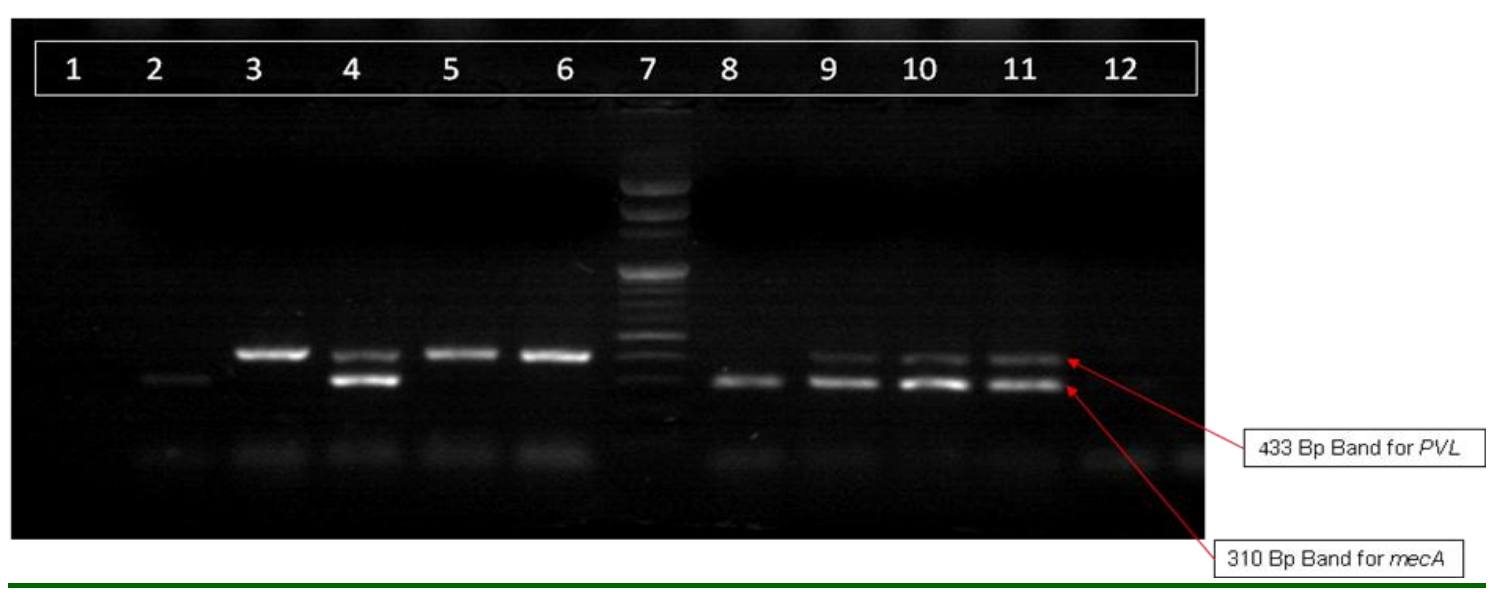

Fig.1 Showed gel electrophoresis of first PCR (PCR-1) products.Showing band for mecA at 310 BP, in sample no 2, 4, 8, 9, 10 and 11.Showing band for $P V L$ at 433BP in sample no 3, 4, 5, 6, 9, 10 and11.

11 - Positive control (mecA gene-ATCCMRSA43300, PVL gene- ATCC25923)

12 - Negative Control (ATCC MSSA 29213)

7- Molecular marker (100bp) 


\section{Molecular characterization of MRSA by PCR-2}

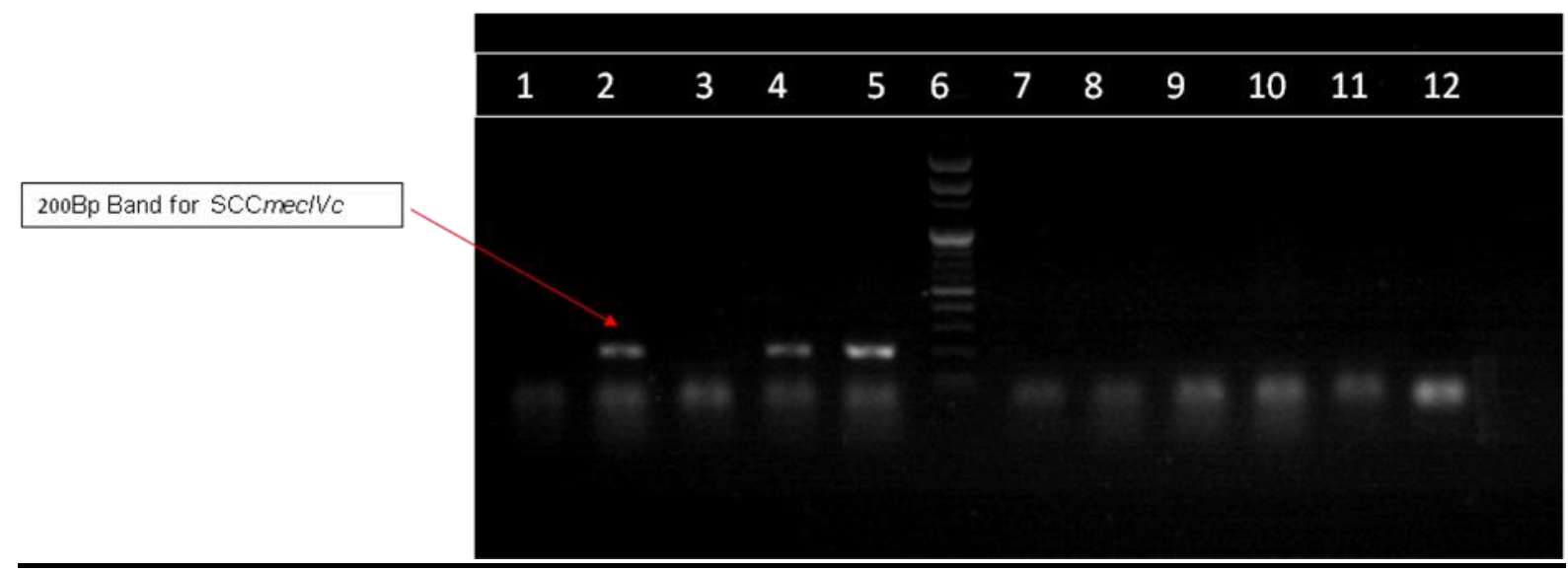

Fig.2 showed gel electrophoresis of second PCR (PCR-2) products. Showing band for SCCmecIVc at $200 \mathrm{BP}$, in sample no 4 and 5.

2 - Internal positive control (Gene Bank accession no- KF710034 and BANK LT 1664623)

1 - Negative Control (ATCC MSSA 29213)

6 - Molecular marker (100bp)

Though Linezolid and vancomycin are reserve drugs but there constant use in future may develope resistance in MRSA.

All the 80 MRSA isolates were subjected to two types of multiplex PCRs. The initial multiplex PCR was done to identify MRSA carrying mecA and $P V L$ gene and in the second multiplex PCR, SCCmec typing and SCCmecIV subtyping was carried out. In the present study mecA was isolated from 72 (90\%) MRSA isolates. The discrimination between the phenotypic and genotypic methods might be because of loss of mecA gene on storage.

Similar type of discrimination was shown by Arjanne van Griethuysen or Olowe. PVL, a necrotizing cytotoxin is considered as specific for the human and rabbit polymorphonuclear cells (Loffler et al., 2010) also an important marker for pathogenic CA-MRSA infections. In developing countries like India (Nagarajan et $a l ., 2010)$ there is high incidence of $P V L$ gene in CA-MRSA. However there have been reports of absence of $P V L$ gene in CAMRSA. In a study conducted by Nagarajan Abimanyu et al., had shown $40 \%$ of MRSA carried the $P V L$ gene. In a study conducted at Mumbai by Namita D'suza et al., had shown the $60 \%$ positivity of $P V L$ gene in MRSA isolates. In the present study also $60 \%$ of MRSA isolates carried the PVL gene which corroborated with the above study findings.

32 MRSA isolates $(40 \%)$ were of $\mathrm{SCCmecIVc}$ type. Further sequences were deposited in gene bank with accession noKF710034and BANK LT 1664623. In this study we found the prevalent strain in the community was multidrug resistant of type SCCmecIVc. Namita D'suza et al., performed MLST of the MRSA strains and found the prevalent strain of SCCmecIVc.

The highlights of this study included compiled, simple and easy format for the identification, susceptibility testing by using 
both phenotypic and genotypic methods for CA-MRSA. The novel features were reporting of multidrug resistant CA-MRSA in communities. For the first time from the local community, we had reported the prevalent circulating strain of SCCmecIVc subtype.

In conclusion, there is a constant rise in MRSA associated with change in epidemiological parameters. There is an ongoing change in prevalence, resistance profile and epidemiology of CA-MRSA strains. Though CA-MRSA carriers are asymptomatic but may act as potent source for spread in the community. Risk factors are not prominently seen with CA-MRSA compared to HA-MRSA.

In India the carriage rate is high because of close community, improper hygiene and poor socioeconomic strata. As the asymptomatic carriers spread the infection along with the toxin facilitates increase in the invasive diseases. There is increasing trend of colonisation in pregnant women apart from the neonates and adults. Initially CA-MRSA were resistant to few antibiotics but in the present study most of the isolates were multidrug resistant. The prevalent strain in the local community is of type SCCmecIVc. Namita D'suza et al., had signified the association of SCCmecIVc with the influenza strain.

Same episodes may occur in the local community (study place). Early identification of carriers and effective antibiotic policy, hand hygiene and decolonisation of the carrier patients are foremost required to prevent the spread in community.

\section{Acknowledgment}

All my lab staff, my collegues.

\section{References}

Abimanyu, N., Krishnan, A., Murugesan, S., Subramanian, G.K., Gurumurthy, S., Krishnan, P. 2013. Use of Triplex PCR for Rapid Detection of PVL and Differentiation of MRSA from Methicillin Resistant Coagulase Negative Staphylococci. J. Clin. Diagn. Res., 7(2): 215-8.

Chua, T., Moore, C.L., Perri, M.B., Donabedian, S.M., Masch, W., Vager, D., et al. 2008. Molecular Epidemiology of Methicillin-Resistant Staphylococcus aureusBloodstream Isolates in Urban Detroit. J. Clin. Microbiol., 46(7): 2345-52.

Clinical and laboratory standard institute. 2012. Performance Standards for Antimicrobial Susceptibility testing. $22^{\text {nd }}$ Informational supplement. CLSI documentM100-S22. CLSI, Wayne, PA.

Clinical and laboratory standard institute. 2012. Performance Standards for Antimicrobial Susceptibility testing. $22^{\text {nd }}$ Informational supplement. CLSI documentM100-S22. CLSI, Wayne, PA.

Clinical and laboratory standards institute. 2009. Methods for dilution antimicrobial susceptibility tests for bacteria that grow aerobically. Approved standard $7^{\text {th }}$ ed. CLSI document M7-A8. CLSI, Wayne, PA.

Crum, N.F., Lee, R.U., Thornton, S.A., Stine, O.C., Wallace, M.R., Barrozo, C., et al. 2006. Fifteen-year study of the changing epidemiology of methicillin-resistant Staphylococcus aureus. Am. J. Med., 119(11): 943-51.

David, M.Z., Daum, R.S. 2010. CommunityAssociated Methicillin-Resistant Staphylococcus aureus: Epidemiology and Clinical Consequences of an 
Emerging Epidemic. Clin. Microbiol. Rev., 23(3): 616-87.

David, M.Z., Glikman, D., Crawford, S.E., Peng, J., King, K.J., Hostetler, M.A., et al. 2008. What is communityassociated methicillin-resistant Staphylococcus aureus? J. Infec. Dis., 197(9): 1235-43.

D'Souza, N., Rodrigues, C., Mehta, A. 2010. Molecular Characterization of Methicillin-Resistant Staphylococcus aureuswith Emergence of Epidemic Clones of Sequence Type (ST) 22 and ST 772 in Mumbai, India. J. Clin. Microbiol., 48(5): 1806-11.

Ito, T., Katayama, Y., Asada, K., Mori, N., Tsutsumimoto, K., Tiensasitorn, C., et al. 2001. Structural comparison of three types of staphylococcal cassette chromosome mec integrated in the chromosome in methicillin-resistant Staphylococcus aureus. Antimicrob. Agents Chemother., 45(5): 1323-36.

Ito, T., Ma, X.X., Takeuchi, F., Okuma, K., Yuzawa, H., Hiramatsu, K. 2004. Novel type V staphylococcal cassette chromosome mec driven by a novel cassette chromosome recombinase, ccrC. Antimicrob. Agents Chemother., 48(7): 263.

Ito, T., Okuma, K., Ma, X.X., Yuzawa, H., Hiramatsu, K. 2003. Insights on antibiotic resistance of staphylococcus aureus from its whole genome: genome island SCC. Drug Resist. Updat., 6(1): 41-52.

Joshi, S., Ray, P., Manchanda, V., Bajaj, J., Chitnis, D.S., Gautam, V., et al. 2013. Methicillin resistant Staphylococcus aureus (MRSA) in India: Prevalence \& susceptibility pattern. Indian J. Med. Res., 137(2): 363-9.

Kaleem, F., Usman, J., Hassan, A., Omair, A., Khalid, A., Uddin, R., et al. 2010. Sensitivity pattern of methicillin resistant Staphylococcus aureus isolated from patients admitted in in a tertiary care hospital of Pakistan. Iran J. Microbiol., 2(3): 143-6.

Kluytmans, J., vanBelkum, A., Verbrugh, H. 1997. Nasal carriage ofStaphylococcus aureus: epidemiology, underlying mechanisms, and associated risks. Clin. Microbiol. Rev., 10(3): 505-20.

Laibl, V.R., Sheffield, J.S., Roberts, S., McIntire, D.D., Trevino, S., Wendel, G.D.Jr. 2005. Clinical presentation of community-acquired methicillinresistant Staphylococcus aureusin pregnancy. Obstet. Gynecol., 106(3): 461-5.

Loffler, B., Hussain, M., Grundmeier, M., Bruck, M., Holzinger, D., Varga, G., et al. 2010. Staphylococcus aureus Panton-Valentine leukocidin is a very potent cytotoxic factor for human neutrophils. PLoS Pathog., 6(1): 1000715.

Lowy, F.D. 1998. Staphylococcus aureus infections. N. Engl. J. Med., 339(8): 520-32.

McClure, J.A., Conly, J.M., Lau, V., Elsayed, S., Louie, T., Hutchins, W., et al. 2006. Novel Multiplex PCR assay for detection of the staphylococcal virulence marker Panton-Valentine leukocidin genes and simultaneous discrimination of methicillin -susceptible from resistant staphylococci. J. Clin. Microbiol., 44(3): 1141-4.

Morrison, M.A., Hageman, J.C., Klevens, R.M. 2006. Case definitionfor community-associated methicillinresistant Staphylococcus aureus. $J$. Hosp. Infect., 62(2): 241.

Moussa, I., Kabli, S.A., Hemaq, H.A., AIGarni, S.M., Shibi, A.M. 2012. A novel multiplex PCR for molecular characterization of methicillin resistant staphylococcus aureus recovered from Jeddah, Kingdom of Saudi Arabia. 
Indian J. Med. Microbiol., 30(3): 296301.

Nagarajan, A., Ananthi, M., Krishnan, P., Reischl, U., Prabha, C., Linde, H.J. 2010. Emergence of Panton Valentine leucocidin among community and hospital associated methicillinresistant Staphylococcus aureus in Chennai, South India. J. Hosp. Infect., 76(3): 269-71.

Olowe, O.A., Kukoyi, O.O., Taiwo, S.S., Ojurongbe, O., Opaleye, O.O., Bolaji, O.S., et al. 2013. Phenotypic and molecular characteristics of methicillin-resistant Staphylococcus aureus isolates from Ekiti state, Nigeria. Infect. Drug Resist., 6: 87-92.

Panlilio, A.L., Culver, D.H., Gaynes, R.P., Banerjee, S., Henderson, T.S., Tolson, J.S., et al. 1992. Methicillin-resistant Staphylococcus aureus in U.S. hospitals, 1975-1991. Infect. Control Hosp. Epidemiol., 13(10): 582-6.

Pathak, A., Marothi, Y., Iyer, R.V., Singh, B., Sharma, M., Eriksson, B., et al. 2010. Nasal Carriage and Antimicrobial Susceptibility ofStaphylococcus aureus in healthy preschool children in Ujjain, India. BMC Pediatr., 10: 100.
Que, Y.A., Moreillon, P. 2010. Staphylococcus aureus (Including Staphylococcal Toxic Shock).In: Mandell GL, Bennett JE, Dolin R, editors. Mandell, Douglas and Bennett's Principle and practice of Infectious Diseases. $7^{\text {th }}$ ed. Philadelphia: Churchill Livingstone; p.2543-78.

Ramana, K.V., Mohanty, S.K., Wilson, C.G. 2009. Staphylococcus aureus colonization of anterior nares of school going children. Indian $J$. Pediatr., 76(8): 813-6.

VanGriethuysen, A., VanLoo, I., VanBelkum, A., VandenbrouckeGrauls, C., Wannet, W., van Keulen, P., et al. 2005. Loss of the mecA Gene during Storage of MethicillinResistant staphylococcus aureus Strains. J. Clin. Microbiol., 43(3): 1361-5.

Wertheim, H.F., Melles, D.C., Vos, M.C., van Leeuwen, W., van Belkum, A., Verbrugh, H.A., et al. 2005. The role of nasal carriage in Staphylococcus aureus infections. Lancet Infect. Dis., 5(12): 751-62.

\section{How to cite this article:}

Prashant Jindamwar, P Roy, C.N. Chaudhary, N. Grover, Patil Shivraj and Khajuriya Atul. 2016. Novel Reporting of Community Acquired Methicillin Resistant Staphylococcus aureus (CA-MRSA) Strain at a Tertiary Care Centre. Int.J.Curr.Microbiol.App.Sci. 5(10): 555-564. doi: http://dx.doi.org/10.20546/ijcmas.2016.510.062 